\title{
Homenagem ao professor José Antonio Dias Garcia
}

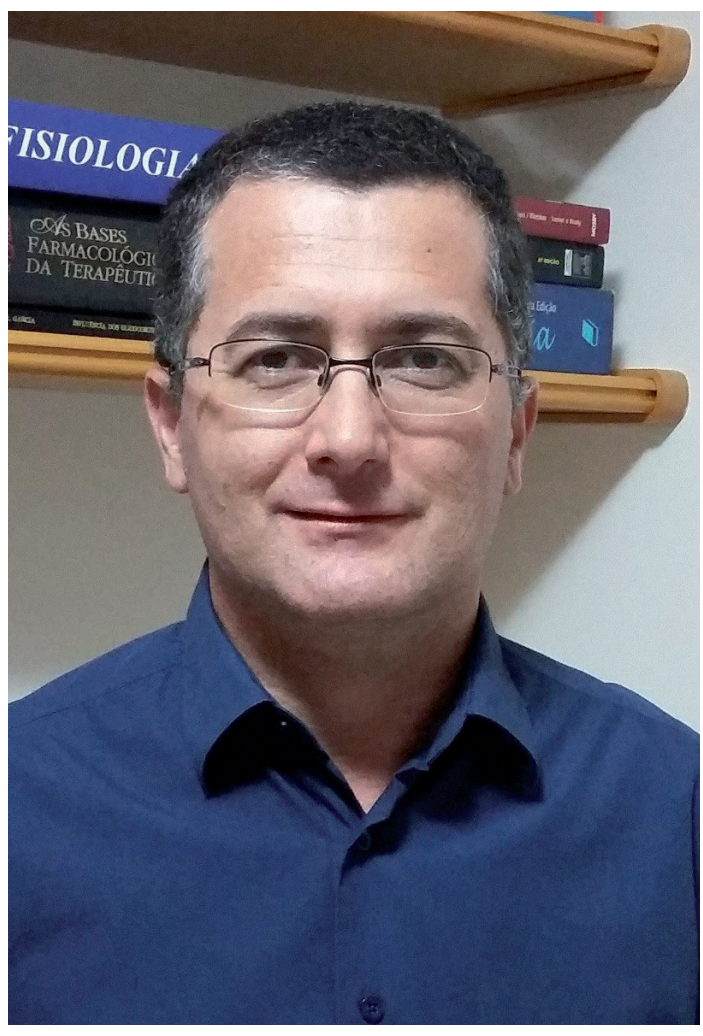

O professor José Antonio Dias Garcia ingressou no curso de Medicina Veterinária na Universidade de Alfenas (UNIFENAS), em fevereiro de 1987. Pessoa de família simples, a vivência em fazenda motivou a escolha do curso, alternativa que considerava a mais promissora para seu futuro. As dificuldades financeiras quase acabaram com seu sonho, mas as oportunidades apareceram e conseguiu formar-se com crédito educativo. 0 crédito educativo pagava as mensalidades escolares e as aulas particulares que ele ministrava para os colegas custeavam seu sustento.

Durante o período acadêmico, não teve oportunidade de desenvolver iniciação científica por falta de incentivo à pesquisa, na época. Hoje, como docente e pesquisador, encoraja seus alunos a participarem dos programas de iniciação científica, pois acredita que ela é a base do conhecimento para pesquisa e ajudará aqueles que desejam ingressar na pós-graduação.

Começou sua carreira docente como professor na UNIFENAS, onde também recebeu o título de

Mestre em Ciências Morfológicas (área de concentração Biologia Celular), em 1999. Possui título de especialista em Fisiologia Animal e Humana pela Pontifícia Universidade Católica de Minas Gerais (PUC Minas) e de doutorado em Biologia Molecular e Funcional (área de concentração Fisiologia) pela Universidade Estadual de Campinas (UNICAMP).

Devido ao seu vínculo empregatício, todo o período de doutorado foi realizado sem bolsa de estudos. Esses anos foram difíceis pelas longas viagens de Alfenas a Campinas, mas foram gratificantes no aspecto profissional e no âmbito pessoal, já que, diante das dificuldades, a obtenção do título de doutor foi uma vitória, além de ter tido a oportunidade de participar de congressos nacionais e internacionais. Publicou artigos em periódicos nacionais e internacionais, entre eles o Journal of Cardiovascular Pharmacology. Realizou estágio de pós-doutorado em investigação científica na Universidade de Coimbra, em Portugal. É professor do IFSULDEMINAS desde 2011 e mantém vínculo com a UNIFENAS no programa de mestrado e doutorado em Reprodução, Sanidade e Bem-Estar Animal.

Dentro do IFSULDEMINAS, desempenha a função de professor e desenvolve pesquisa nas áreas de Reprodução Animal, com dois projetos aprovados pelo Conselho Nacional de Desenvolvimento Científico e Tecnológico (CNPq), dentro da linha de biotecnologia e inovação, em associação com empresas particulares e com instituições de ensino. Faz parte do corpo docente e é orientador no programa de Mestrado Profissional em Ciência e Tecnologia de Alimentos do IFSULDEMINAS. Coordena o Comitê de Ética no Uso de Animais (CEUA/IFSULDEMINAS), é bolsista de Desenvolvimento Tecnológico Industrial do CNPq - Nível B e é avaliador da Revista Agrogeoambiental. 
O professor José Antonio escreve "Hoje, vejo que fiz uma trajetória diferente da maioria dos recém-graduados, que saem da graduação para a especialização, mestrado, doutorado e até pós-doutorado para, depois, ingressarem no mercado de trabalho. Tenho certeza de que o caminho que segui foi difícil e importante para minha vida profissional, pois adquiri maturidade, experiência e os problemas e dúvidas científicas que surgiram foram solucionados nas pós-graduações. Assim, meu aprendizado foi baseado nos problemas e dúvidas da vida profissional. Aproveito para pedir aos alunos e colegas que nunca esgotem seus sonhos e a vontade de concretizá-los". 